\section{SOI: 1.1/TAS DOI: $10.15863 /$ TAS \\ International Scientific Journal Theoretical \& Applied Science}

p-ISSN: 2308-4944 (print) e-ISSN: 2409-0085 (online)

Year: 2017 Issue: 02 Volume: 46

Published: $28.02 .2017 \quad \underline{\text { http://T-Science.org }}$
Madaminbek Khatamovich Akhmedov scientific doctor from biology, professor of Zoology division in

Andijan State University (Uzbekistan)

Alijon Karimovich Khusanov the eldest scientific co-worker of Zoology division in Andijan State University, Andijan State University, a_xusanov75@mail.ru

SECTION 11. Biology. Ecology.

Veterinary Medicine.

\title{
THE DEVELOPMENT OF MECHANICAL DEFENSIVE BEHAVIOR OF HOMOPTEROUS INSECTS IN THE "PARASITE HOST" SYSTEM
}

Abstract: The current article investigates the uniquepassive defensive strategies of homopterous insects in the "parasite-host" system. The morpho-ecological differentiation of different forms of wax extractions in the hypoderma among homopterous insects was divided into two directions: Diffused wax rust-fluff-crumby powder and tight wax. 2. Diffused wax rust-fluff-glassy extraction-plate and dashboard.

Key words: gipoderma, fluffy fiber, coins, shields, "the host of the parasite", white soft, wax.

Language: English

Citation: Akhmedov MK, Khusanov AK (2017) THE DEVELOPMENT OF MECHANICAL DEFENSIVE BEHAVIOR OF HOMOPTEROUS INSECTS IN THE "PARASITE HOST" SYSTEM. ISJ Theoretical \& Applied Science, 02 (46): 33-35.

Soi: http://s-o-i.org/1.1/TAS-02-46-7 Doi: crossef https://dx.doi.org/10.15863/TAS.2017.02.46.7

\section{Introduction}

As it was observed in major supplying with plants, the altered forms of hypoderm, which are formed as a result of cooled wax extractions, in turn develop fluff fiber that serve as a shield, i.e. passivemechanical defensive strategy. It is known that this type of adaptation is represented as one of the adventive types of morphologic adjustments, where the bodies of Pseudococcus citri Fern., Saissetia oleae Ckll., Cinara grossa Kalt., Eulachnus alticola Born., Eulachnus tauricus Bozh., Macrosiphum euphorbiae Thom., Bemisia tabaci Gen., Trialeyrodes vaporarioum Westw., Dialeurodis citri Riley are covered with wax ashes and protective shields, while the bodies of Pseudococcus comstoki Kuv., Eriosoma lanigerium Hausm. are covered with dark yellow or white fluff $[4,48 ; 5,56 ; 6,48 ; 8$, 143].

It is important to state that the bodies of such species as Gymnaspis aechmeae Newst., Pinnaspis aspidistra Ldgr., Leucaspis archangelskyae Ldgr., Diaspis bromeliae Sign., Diaspis zamiae Mofg. are covered by shield.

\section{Materials and Methods}

Generally, if we compare the statistics between the bodies of insects which are covered by wax ashes and shields protected by adventive types, the latter composes $62 \%$ (18 species), among them 9 insects are covered with shields. Bodies of plant louse and white-winged insects are covered with wax of crumby ashes and the indicators make up 31\%, 2 of them are shield types and plant louse (6.9\%) are covered by wax.

It is found out that homopterous proboscissucking insects develop passive protection if specialized nutritive plants are applied, which is the cause of diversified wax extractions. Hence, while comparing the process of improvement with the family of further species, the process becomes more complicated in the system of thick fluff wax ashes and shields. (See attached figure below).

Generally, the diversification of wax extractions depends on the type of species, nutritive plants, place of dwelling and on the detachment of its excrements. For example, the bodies of the members in the family of Margarodidae are covered with long glassy wax fibres, while the bodies of Pseudococcidae insects are covered with visible floury elements and wax extractions. In some types of insects it is possible to notice the scales that belong to the family of komstoki worm which, in turn, possess the body covered with wax ashes and fluff (Picture 1). 


\begin{tabular}{|c|c|c|c|c|c|c|}
\hline Impact Factor: & $\begin{array}{l}\text { ISRA (India) } \\
\text { ISI (Dubai, UAF } \\
\text { GIF (Australia) } \\
\text { JIF }\end{array}$ & $\begin{array}{l}=1.344 \\
=0.829 \\
=0.564 \\
=1.500\end{array}$ & $\begin{array}{l}\text { SIS (USA) } \\
\text { PИНЦ (Russia) } \\
\text { ESJI (KZ) } \\
\text { SJIF (Morocco) }\end{array}$ & $\begin{array}{l}=0.912 \\
=0.234 \\
=1.042 \\
=2.031\end{array}$ & $\begin{array}{l}\text { ICV (Poland) } \\
\text { PIF (India) } \\
\text { IBI (India) }\end{array}$ & $\begin{array}{l}=6.630 \\
=1.940 \\
=4.260\end{array}$ \\
\hline
\end{tabular}

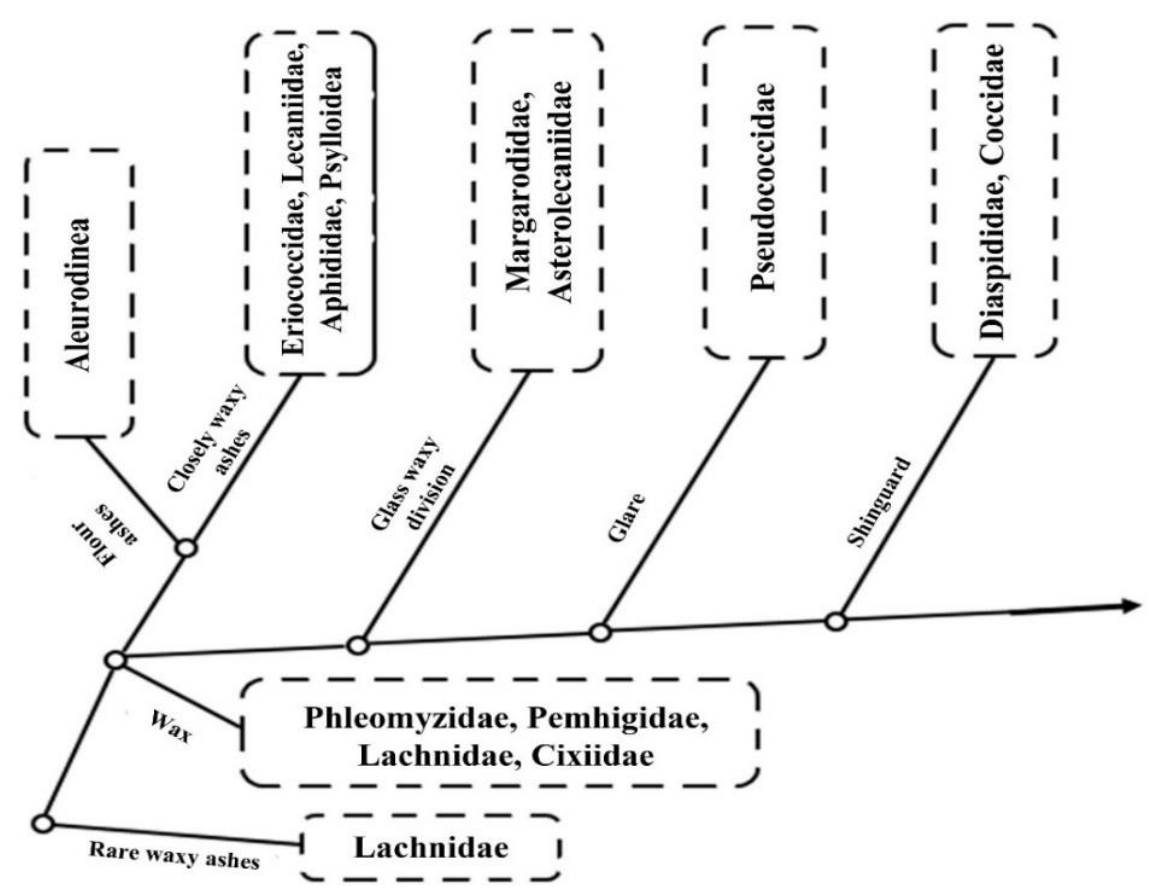

Picture 1 - Some types of insects it is possible to notice the scales that belong to the family of komstoki.

The bodies of such female species as Ortheziidae possess fully white or half white, fully grey or half grey wax scales.

The bodies of such member as Asterolecaniidae are covered with thin graceful glassy separate wax elements.

The wax separations bring incredible changes for artificial (Coccidae) shields of wax extractions by altering the bodies of horn species dramatically after birth testicle.

Real (Diaspididae) leather and horned shields usually have thin bringt and half bright features, moreover, in some species shoulders and stomach of the host develop together and the parasite develops between those two shields.

Generally, wax separations of coccids, their particular forms and special features are consider as their systematic signs [2, 12-28; 1,13$]$.

From the above mentioned discussions it can be concluded that the forms of wax extractions in the family of primitive evolutionary coccids have been developed into more and more complex process. The particular defensive features of passive coccids, their eating and living habits in the "parasite-host" system have been developed from historical perspective step by step in the following order: Margarodidae Pseudicoccidae - Ortheziidae - Asterolecaniidae Coccidae - Diaspididae.

It is important to draw attention to the significant note about the homopterous proboscissucking insects that usually do not dwell in open area colonies but rather prefer to develop in the bodies of the host secretly or half secretly, hence they can adapt to the different environments even under the surface.

Plant louse in the type of Pemphigus Hart., Eriosoma Leach., Kaltenbachiella Schout., Tetraneura Hart., Slavum Mordv. Which belong to the gall plant louse cover its body with fluff, which protects the plant from produced "plant louse" within the gall as well as from unnecessary moisture. We may observe the similar pattern among such insects as Prociphilus xylostei Deg., P.umarovi Narz., where the parasite lives in a half secret way.

For example, the plant louse (Phleomyzidae, Lachnidae, Pemphigidae, Drepanosiphidae ва Aphididae) that can be found in Central Asia is expressed as the member of family in the body of wax extractions, and took the formof fluff and wax ashes. Moreover, the most primitive member of the Phleomyzidae family known as Phloemyzus passerinii (Sing.) is located in the crack of polar and before attaching to its host it covers the body with ample fluff.

Similar process can be observed in the example of Shivaphis celticola Nevs., (Drepanosiphidae) that lives in (Celtis australis, C.caucasia). Moreover, fluff of plant louse Cinara thujafilina (Del Guercio) that belongs to the family of Lachnidae is easily determined $[7,28 ; 8,143]$.

It can be observed that most of the types of Aphididae plant louse is covered with wax ashes. For example, among the Macrosiphoniella del Guerc. plant louses, especially among the members of Macrosiphoniella seed the ashes replace scleritestructures in tergite. It is known that the 


\begin{tabular}{|c|c|c|c|c|c|c|}
\hline Impact Factor: & $\begin{array}{l}\text { ISRA (India) } \\
\text { ISI (Dubai, UAE } \\
\text { GIF (Australia) } \\
\text { JIF }\end{array}$ & $\begin{array}{l}=1.344 \\
=0.829 \\
=0.564 \\
=1.500\end{array}$ & $\begin{array}{l}\text { SIS (USA) } \\
\text { PИНЦ (Russia) } \\
\text { ESJI (KZ) } \\
\text { SJIF (Morocco) }\end{array}$ & $\begin{array}{l}=0.912 \\
=0.234 \\
=1.042 \\
=2.031\end{array}$ & $\begin{array}{l}\text { ICV (Poland) } \\
\text { PIF (India) } \\
\text { IBI (India) }\end{array}$ & $\begin{array}{l}=6.630 \\
=1.940 \\
=4.260\end{array}$ \\
\hline
\end{tabular}

parasite plant Macrosiphoniella depends on its host Artemisia L., thus the former had to adapt to live in xerophilous conditions. The wax ashes that cover the body of the insect prevent the parasite from the excess loss of water. Wax ashes can be referred to such seed types as Dysaphis Born., Brevicoryne Das., Cryptosiphon Prantl., Brachyunguis Das., Hyalopterus Koch., Hyadaphis Kirk., Coloradoa Wilson., Anuraphis Guerc., and to some members of Aphis L. Seeds.

The special importance draws attention the passive defensive strategies of Ferganaphis Mukch., types of seeds. Such plant louses copy some features from morphological perspective of Lachninae, Macrosiphoninae and Anuraphidinae group of insect, covering themselves with abundant fluff, which makes those parasites similar to the Pemphigidae family members [3, 12]. Likewise, the plant louse Xerobion eriosomatinum Nevs. Cover tergite in a noticeable length with white fluffy fibers. As the appropriate season comes they cover themselves with abundant white fluff nutritive plant known as Kochia $[9,38 ; 10,28]$.

\section{Conclusion}

We can see in some families of Aphididae that protect themselves basically with waxy ashes.

The seed Ferganaphis Mukch., has own facility that passive in their protection.

Mainly stated that evolutional ashes in dilapidated troop were passive protection, the youngest progressive type was thick waxy ashes.

The family Cixiidae that live in steppe under the earth is protectable from high moisture and from water.

The maggots waxy filament Psylloidea reduces the consumption to water and keep from dryness.

White wings help the prepared waxes at accommodation to nourishing plant, it executes the role of strong protection.

All confirmed about proboscis-sucking insect live at condition changing ambiences as well as adjust to supply inwardly plants and duplication or in majority of the positions be protected from predator and parasite, also, gives the chance to remain unharmed under chemical poison.

\section{References:}

1. Abdrashitova NI, Gabrid NV (2005) The methodical allowance on collection, study and determination coccid and aphids tree and shrubbery Kyrgyz. National academy of the sciences Republics of Kyrgyz:-Bishkek, 2005.$82 \mathrm{p}$.

2. Archangelskaya AD (1937) Coccid central Asia. Pub. The Committee of the sciences of the Tie.SSR. - Tashkent, 1937. 158 p.

3. Akhmedov MK (1995) Aphids - afididy (Homoptera, Aphidinea Aphididae.) arid, mountainous regions of Central Asia (ecology, faunogenesis, taxonomy). Abstract. Dis. ...Doctor. biol. Sciences.-Tashkent, 1995. - 45 p.

4. Borkhsenius NS (1950) Mealybugs and scale insects of the USSR (Coccoidea) Leningrad: 1950.-p.250.
5. Borkhsenius NS (1966) Catalog scale insects of the world fauna. M - L.: Nauka, 1966. - 450 p.

6. Danzig EM (1964) Suborder Aleyrodinea aleurodids or Whiteflies, Suborder coccidia or mealybugs and scale insects // Key to the insects of the European part of the USSR. 1964. -T.1. -M.-L.: Science. - 616 with.

7. Zokirov II (2009) Aphids lachninae of Uzbekistan (Homoptera, Lachninae) (the life, cycles, etology,): Kondedat sciences on biologies ....diss. -Toshkent, 2009. - 120 p.

8. Ivanovskaya OI (1977) Aphids Western Siberia. -Novosibirsk Science. Sibirsk. Dep, 1977 Part 1 -p. 272.

9. Nevsky VP (1929) The aphids to central Asia. UzOSTAZRa. -Tashkent, 1929. - №16. 417 p.

10. Rupays AA (1989) Aphids (Aphidoidea) Latvia. -Riga: Zinatne 1989. -331 p. 